\title{
Behind Every Successful Woman, There Are a Few Good Men
}

\section{Talitha M. Washington}

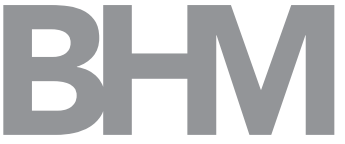

I am fortunate that throughout my mathematical journey, I have had a few good men give me the courage, persistence, and drive to persist in mathematics. I share my story in the hopes that those needing courage receive it and those who can offer help give it. Society may not be just, but each of us can add goodness in all that we do.

As an undergraduate I went to Spelman College, a Black woman's college in Atlanta, Georgia. College was a huge class shock for me, because I grew up in the inner city of Evansville, Indiana, where many of my friends ended up going to jail or prison. At Spelman, I was immediately blessed with not being the only Black female in the class. For the first time in my educational experience, I did not have to be the "negro representative" who is called upon to explain and defend Black people. I did not have to explain my race or why I look this way. Rather, I could simply learn and absorb copious amounts of knowledge centered around my perspective as a Black woman in a multicultural world.

As an undergraduate, I had zero aspirations of going to graduate school. I wanted to work in the business world because that is what I thought I knew. Then along came Jeffrey Ehme (Figure 1), who took me on as a student researcher and in my senior year forced me to apply to graduate school. Had he not made me apply, I would not be here today as a mathematician, and you would not be reading this article.

Life in graduate school at the University of Connecticut was hard. People always asked me what country I was from. That was confusing to me. I later found out that I

Talitha M. Washington is associate professor of mathematics at Howard University. Her email address is tal i tha.washington@ howard. edu. See a write-up of her talk at the 2017 SIAM annual meeting Hidden Figures event www. siam . org/meetings/an17/ figures.pdf.

For permission to reprint this article, please contact: reprint-permission@ams . org.

DOI: http://dx.doi.org/10.1090/noti1634

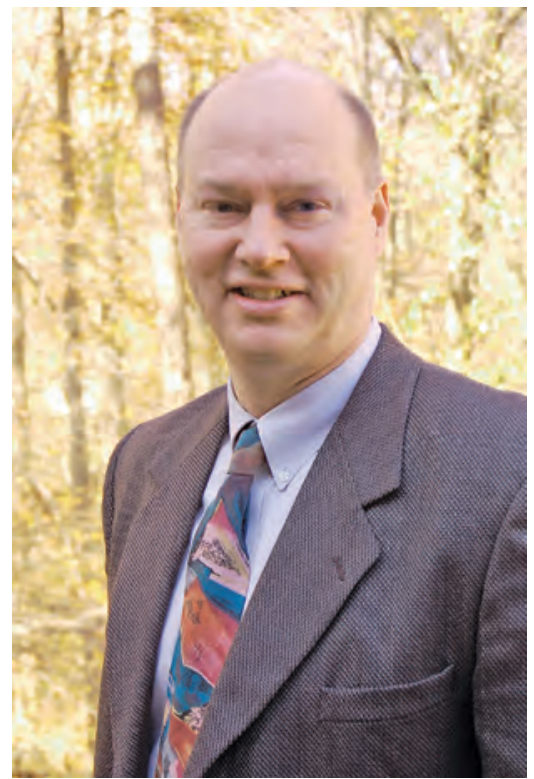

Figure 1. Jeffrey Ehme took me on as an undergraduate research student and forced me to apply to graduate school.

McKenna researched. I was more interested in mathematical biology; so I completed my dissertation under Yung-Sze Choi on a partial differential equations model of proteins acting as on/off switches. In 2001, I became the first African American to graduate with a doctorate in mathematics from the University of Connecticut.

Much of my professional career has been guided by Ronald E. Mickens of Clark Atlanta University ${ }^{1}$ (Figure 3). I knew him as an undergraduate because Clark Atlanta was literally right across the street from Spelman. I remember that when I was an undergraduate he gave me his book on difference equations, which tended to gather dust over the

${ }^{1}$ See Mickens's article on "Nonstandard Finite Difference Schemes" in the January 2018 Notices. 


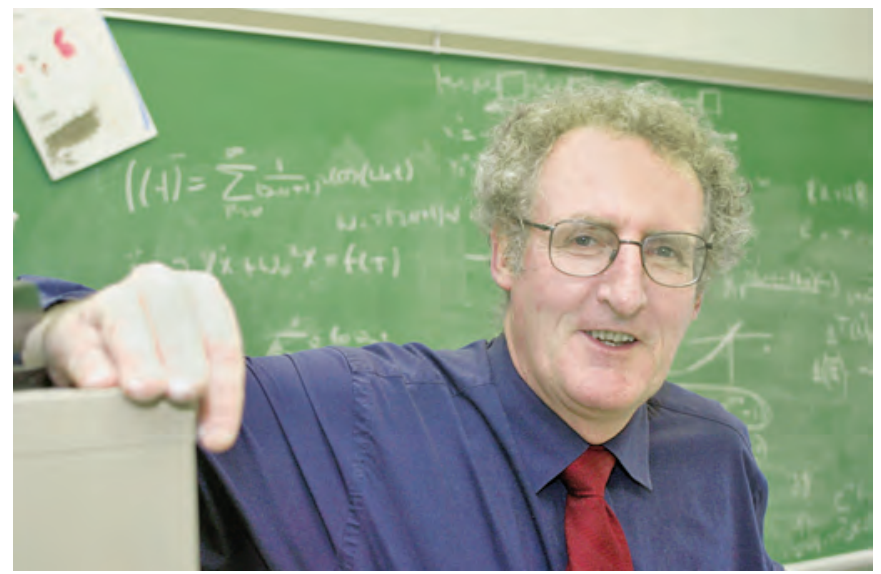

Figure 2. In graduate school at the University of Connecticut, Joe McKenna told me, "You outwork anyone here. You are good."

years. Little did I know that a decade later we would do research together. Over the years we have published papers on the construction of nonstandard finite difference schemes. These schemes discretize dynamical systems and maintain dynamical consistency by incorporating features of the dynamical systems into the discretizations. We now talk a couple of times a week about math, life, and what I should be doing and how I should do it. My graduate student at Howard University, Seye Adekanye, chose to work on the development of nonstandard finite difference schemes of the Tacoma Narrows Bridge for his dissertation. For me his work is a beautiful union of both McKenna and Mickens, two men who continue to inspire my mathematics.

At Howard our departmental meetings are held in a room with that grand picture of Elbert Frank Cox (Figure 4). In 1925 Cox became the first Black in the world to earn a doctorate in mathematics. I did not learn about Cox until I was grown, even though we grew up in the same neighborhood in Evansville, Indiana. Cox was hidden to me. He spent most of his professional career at Howard, as do I. When I sit in departmental meetings, I tend to space out and catch myself staring at his photo and he stares back, encouraging me to continue the pursuit of mathematics and justice.

I'm thinking back to Katherine Johnson, who was featured in the Hollywood movie Hidden Figures, surrounded by white males at NASA. Every time they asked her to do something, she outworked them and did more. She was able to do this because of her mathematical research training at West Virginia State University, a Historically Black University. When she entered West Virginia, so did her professor William Claytor, who is also a Howard graduate. She once asked Claytor, "If I got into math, will anyone hire me?" Claytor replied, "You'll have to see.... That is your problem." Claytor knew that she should pursue mathematics. After graduating, the president of her alma mater, John Davis, a Morehouse man, handpicked her to integrate West Virginia public schools in a graduate program, for he also knew she should pursue mathematics. She enrolled in a summer session, but her training in math was so good that no course could duplicate what she already knew from Claytor.

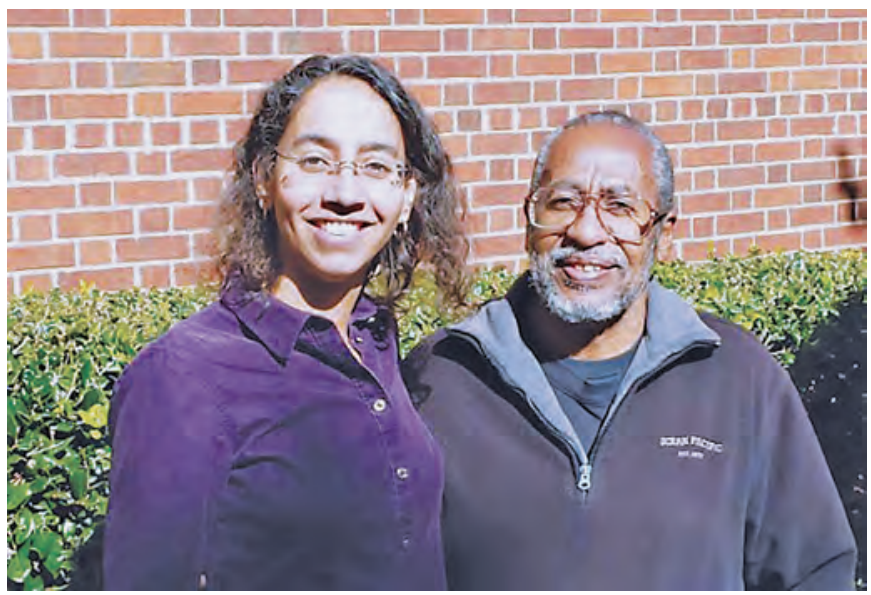

Figure 3. Much of my professional career has been guided by Ronald E. Mickens of Clark Atlanta University.

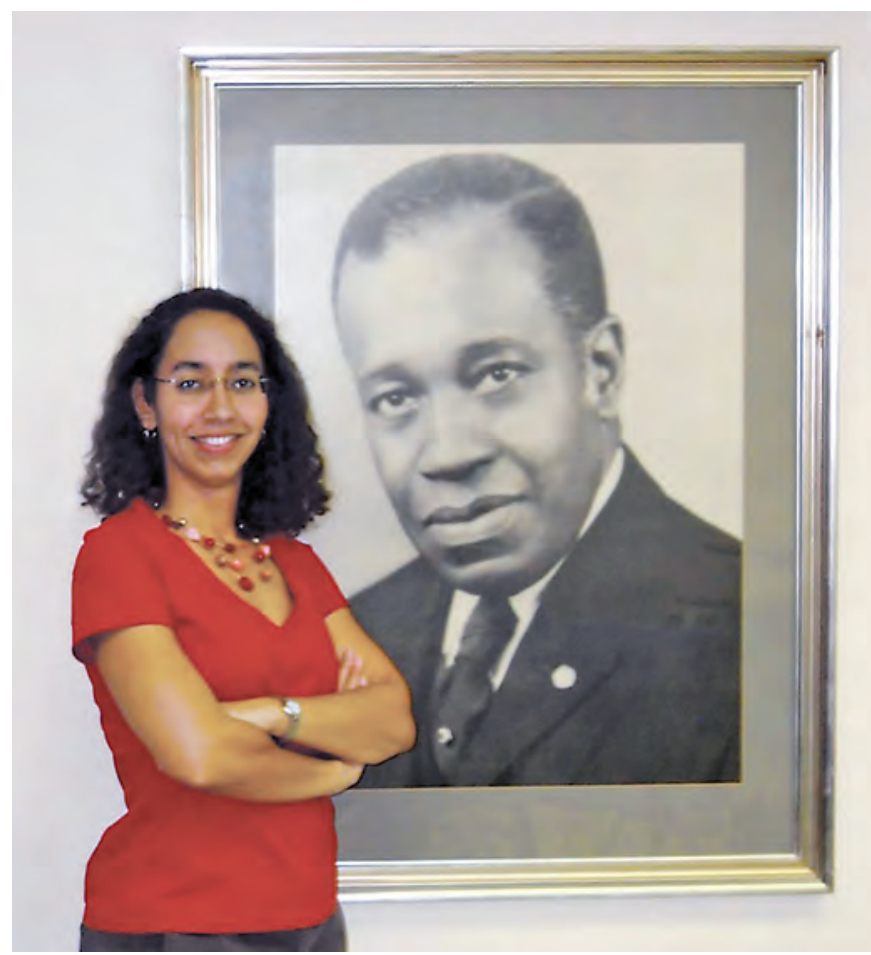

Figure 4. At Howard University, I stand by the grand photo of Elbert Frank Cox, the first Black in the world to earn a doctorate in mathematics. 


\section{BLACK HISTORY MONTH}

\section{so that our children \\ can see that they too can become mathematicians}

This past summer while driving to the SIAM meeting in Pittsburgh, Pennsylvania, I passed through West Virginia. I happened to glance over and see a road sign that read "West Virginia State University." Sitting right beside me was my teenage daughter, snoring away, wearing her Hidden Figures T-shirt. As a mathematician, mother, and activist, I hope that we all remain unhidden so that our children can see that they too can become mathematicians. I am deeply thankful for those few good men who helped me along my way so that I could become an unhidden research mathematician.

\section{Photo Credits}

Figure 1 by Maria Ehme.

Figure 2 courtesy of the University of Connecticut.

Figures 3 and 4 courtesy of Talitha Washington.

Author photo @Lifetouch Portrait Studios, Inc.

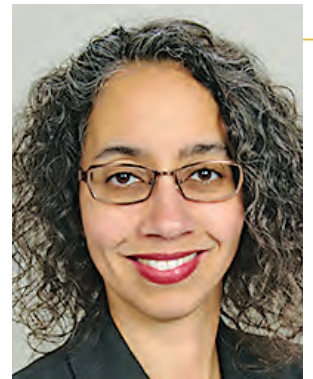

Talitha M. Washington

\section{ABOUT THE AUTHOR}

Talitha M. Washington is interested in applications of differential equations to problems in biology and engineering, as well as the development of nonstandard finite difference schemes to numerically solve dynamical systems. Her three teenagers are STEM bound. In her spare time, she enjoys kickboxing, weight- lifting, aerobics, running, and yoga. 